\title{
Examining the Feasibility of Tea Futures in India
}

Rajat Bhattacharjee $^{+*}$ and Dr. Santosh Kumar Mahapatra ${ }^{*}$

\section{Abstract}

The commodity derivative market in India has gained an important place in the last few decades. However, the entry of 'tea futures' in the derivative market is yet to come. Tea is a substitute for coffee and has a good market worldwide. India's contribution to world production of tea is significant, but the presence of tea futures in Indian derivative market is yet to be seen whereas coffee, being a similar commodity, has a good place in the derivatives market. This study makes an attempt to examine the feasibility of tea futures in India by studying two leading conditions for tea in comparison with coffee. The study examines the market conditions by studying the export potentiality that signifies the demand and supply; and price volatility of tea price. The observations and analysis find favourable grounds for the introduction of tea futures in the commodity derivative market to extend the benefits to various groups like tea growers and manufacturers.

Keywords: Tea; Coffee; Commodity Derivatives; India

\footnotetext{
${ }^{\dagger}$ Assistant Professor in Royal School of Commerce under Royal Global University, Guwahati, Assam, India ${ }^{*}$ Corresponding Author, Email: rajat.bhattacharjee2005@gmail.com

${ }^{¥}$ Associate Professor, Department of Commerce, Gauhati University, Guwahati, Assam, India, Email: skmahapatra@gauhati.ac.in

(C) 2020 Bhattacharjee \& Mahapatra. This is an Open Access article distributed under the terms of the Creative Commons Attribution License (http://creativecommons.org/licenses/by/2.0), which permits unrestricted use, distribution, and reproduction in any medium, provided the original work is properly cited.
} 


\section{Introduction}

Commodity markets in India have a considerable potential since Indian economy is conventionally an agriculture-based economy and agriculture contributes for about 16 per cent to the Gross Value Added of the Indian economy with the employment of 54.6 per cent of the total workforce in the year 2018-19. ${ }^{1}$

The producers of commodities are subject to the risk of low output and poor quality of products owing to factors related to weather, harvest, storage and price fluctuations for the produces. The market prices are influenced by the changes in demand and supply, which leads to the sharp volatility in the price of the commodities. Changes in price bring about market adjustments and uncertainties regarding the revenue for the produce. The imminent risks resulting from such price changes need to be well protected for a stable economy. The process of containing such price volatility by establishing equilibrium between the present and future price of the commodities is known as price discovery. The price discovery mechanism is essential for building an efficient financial system, reflecting the relative costs of production and consumption utilities. Commodity derivatives are useful tools in the discovery of price.

A commodity derivative is a contract between two parties which derives its value from an underlying commodity. These exist in the form of forwards, futures, options and others. Commodity futures are exchange-traded contracts, or agreements, undertaken to buy or sell a specified quantity of the commodity in a designated future period at a pre-determined price agreed upon by the seller and buyer. Futures contracts have certain standardised specifications relating to quality, quantity, and time of the delivery. Futures facilitate the process of price discovery and hedging. Hedging helps in managing the uncertainties brought in

\footnotetext{
${ }^{1}$ Department of Agriculture, Cooperation and Farmers Welfare, 2019, Government of India.
}

by the price movement of commodities and thus helps in risk management.

The commodity derivative market in India has its roots with the first organised future trading in cotton, which started in the year 1875 by the Bombay Cotton Trade Association. Following this, an independent institution was formed in the year 1893. Since then, many commodity exchanges started their operation, and by the year 1939, there were more than 300 such commodity exchanges in India offering derivative contracts on various commodities. However, these commodity exchanges were not regulated by any independent regulatory body and were functioning without any proper policies and direction. Based on the recommendations of Shroff Committee in 1950, the Government of India promulgated Forward Contracts (Regulation), 1952 and set up the Forward Market Commission in the year 1953 to act as the regulator. Over the period, several committees like Dantwala Committee, Khusro Committee, Kabra Committee, Expert Committee on National Agricultural Policy and Abhijit Sen Committee have suggested for various reforms in the derivatives market (Rajib, 2014). It is only in the year 2000 that the Government permitted futures trading in the large number of commodities on the recommendation of the Expert Committee on National Agricultural Policy.

At present, India has six national commodity exchanges namely, Multi-Commodity Exchange (MCX), National Commodity and Derivatives Exchange (NCDEX), National Multi-Commodity Exchange (NMCE), Indian Commodity Exchange (ICEX), Bombay Stock Exchange (BSE) and National Stock Exchange (NSE) in addition to the regional exchanges. The Forward Markets Commission (FMC), set up in 1953 as the regulating agency, was merged with the Securities and Exchange Board of India (SEBI) in 2015.

The annual turnover of commodity derivatives in India, as presented in Table 1, shows how the 
commodity derivatives market in India has witnessed fluctuations in the total value of trade over the years. Many reforms have been introduced in order to revamp and make the commodity derivatives market efficient. The tradable commodities in India are mainly classified into four categories - Metal, Energy, Bullion and Agriculture. A few items traded in the agricultural derivatives market are guar seed, castor seed, Bengal gram (chana), soybeans, cocoa, coffee, cotton, rice, sugar and many others.
The question remains as to why tea has not yet entered the commodity futures market and an investigation into this is highly desired. This paper is organised as follows. The study begins with a brief review of the literature, which examines the previous studies relating to commodity derivatives in order to identify the research gap. Following this, it explains the specific objectives, methodology and data source. The final section reports the analysis and findings of the study and conclusion.

\begin{tabular}{|c|c|c|c|}
\hline Years & $\begin{array}{l}\text { Value of Trade } \\
\text { (INR in Millions) }^{1}\end{array}$ & Years & $\begin{array}{l}\text { Value of Trade } \\
\text { (INR in Millions) }^{2}\end{array}$ \\
\hline 2009-10 & $77,647,540.5$ & 2014-15 & $61,356,720$ \\
\hline 2010-11 & $119,489,423.5$ & $2015-16$ & $66,963,810$ \\
\hline 2011-12 & $181,261,037.8$ & 2016-17 & $64,996,370$ \\
\hline 2012-13 & $170,468,400.9$ & 2017-18 & $60,225,300$ \\
\hline 2013-14 & $101,447,949.8$ & 2018-19 & $73,779,450$ \\
\hline
\end{tabular}

\section{Review of Literature}

After identification of the broad research problem, a review of the existing literature has been made in relevant areas to understand the level of studies made so far and the scope for the researchable problem. The summary of the reviews has been categorically placed under different headings.

In the studies of Dey \& Sivakumar (2012); Barot \& Gajjar (2013); Bansal et al. (2014), Bhagwat et al. (2015); and Maravi (2015), we observed discussions on the evolution, growth and performance of derivatives market. All these studies are indicative of the fact that the derivatives market in India has strong growth potential. Naik \& Jain (2002); Singh (2004); Roy (2006); Lokare (2007); Kumar \& Pandey (2009); Biswas \& Rajib (2012); and Ravi (2013) have focused on the issue of price risk management in their works. Some of these studies observed that a few of the agricultural commodities market, where derivatives exist, are found to be efficient in terms of price risk management. In contrast, some other research works have found inefficiency in providing an efficient hedge against risk from price volatility in the Indian market. Overall, it can be said that managing price-risk is reasonably well in the Indian derivatives market. However, the efficiency in reducing the risk in commodity exposure is not that strong.

Bryant \& Haigh (2004); Ahuja (2006); Nath \& Lingareddy (2008); Kaur \& Rao (2009); Mukherjee (2011); Mallikarjunappa (2012); and Sharma (2013) in their research works, studied on the relationship between spot and futures price and found a positive and robust correlation between futures and spot prices of selected commodities. The overall analysis of the riskreturn relationships of commodities shows the existence of a high degree of a positive correlation between risk and returns in the Indian commodity futures market. As per these studies, a strong causal relationship prevails between the spot and futures markets, but the spot and future prices for some of the selected agricultural commodities are efficient in a weak form showing a mixed result on the relationship between spot and futures price. Pennings \& 
Leuthold (2001); Kumar et al. (2012); and Sivarethinamohan \& Aranganathan (2013), in their research papers, have stressed on the importance of behavioural decision making in the operations of a commodity futures exchange. Brorsen \& Fofana (2001); Shim (2006); Hosseini-Yekani et al. (2009); Zhang (2012); and Qehaja (2014) have concentrated on the various factors influencing the success or failure of futures contracts, especially in case of agricultural commodities.

From the various studies made in the field, it is observed that attempts have been made by many to study the Indian Commodity Derivatives Market relating to price discovery, price volatility, growth and performance. Researchers have worked on the surface of agricultural commodity derivatives markets, studying various aspects like the impact of derivatives on inflation, progressive role in the development of the nation, but studies concerning absence of few commodities in the derivative market and the reasons behind this have not been investigated so far. Tea is one such genre, which remains unexplored in the derivatives market in India. In contrast, coffee, a substitute for tea has a well-established place in the Indian futures market. Although researchers have studied a few individual commodities and their feasibility of commodity futures in some countries, no such study is found in case of tea. At this backdrop, we propose to investigate the reasons behind the absence of tea futures in the Indian derivative market and examine the feasibility of introducing 'tea futures' in India.

\section{Methodology}

This study is carried out to examine the feasibility of launching commodity futures in tea in India. Raipuria (2001), in the study Report on the Group of Forwards and Futures Markets, has identified certain essential pre-requisites, to consider the suitability of a commodity for futures trading and two of these pre-requisites are: (1) the commodity should have suitable demand and supply conditions, that is, volume and marketable surplus should be large; and (2) prices should be volatile to necessitate hedging through futures trading.
In the present study, an attempt has been made to examine the demand and supply of tea; and price volatility that justifies the necessity of hedging. Thus, the prime objective of this study is to examine the feasibility of tea futures in the Indian derivatives market in terms of (i) the demand and supply of tea and (ii) the price volatility.

As stated above, the first issue in this study is to examine the feasibility of tea future in the Indian commodity market. This can be done through a study on demand and supply of tea vis-à-vis coffee. The demand and supply of tea and coffee can be best judged from the export value of those produces as export denotes the demand/supply at the international market and can be accepted as an indicator for the demand of a product. If the demand pattern in tea and coffee are found similar, we can infer that demand for both exist and it could be taken as a favourable condition for the introduction of tea futures. Accordingly, the following null and alternative hypotheses have been formulated for testing and drawing an inference.

$H 1_{0}$ : There is no significant difference between the export value of tea and coffee.

$H 1_{1}$ : There is a significant difference between the export value of tea and coffee.

Again, the second issue is to examine the price volatility of tea as compared to that of coffee to know whether price volatility in tea exists like that of coffee. Accordingly, the following null and alternative hypotheses have been developed.

$\mathrm{H} 2_{0}$ : There is no significant difference between the price volatility of tea and coffee.

$\mathrm{H}_{2}$ : There is a significant difference between the price volatility of tea and coffee.

The study is based entirely on secondary data. The data has been collected from two major sources for the time period 2001 to 2017, namely (i) Indian Tea Association, and 
Market Research and Intelligence Unit Coffee Board.

The exports in value have been obtained by making necessary adjustments that is multiplying the number of exports with export price per unit. The reason behind using the export price per unit is that the turnover would reflect the potential of the commodity to generate revenue in terms of foreign exchange to the Exchequer of the Government of India.

Quantitative and statistical measures like Compound Annual Growth Rate (CAGR), standard deviation, and coefficient of variation have been used to understand the growth and price volatility of tea vis-à-vis coffee and draw inferences. The application of t-test also enables to strengthen further the inferences drawn.

\section{Findings}

The various research works cited earlier revealed great demand and supply to be one of the commodities attributes influencing the success or failure of futures contracts. The export value of tea and coffee for the period of 2001 to 2017 is presented in Table 2, along with a graphical representation in Figure 1 while the CAGR of the exports is presented in Table 3. The CAGR of tea and coffee for three phases namely 2001-2017, 2007-2017 and 2012-2017 with a time interval of 17 years, 11 years and six years respectively have been computed and reported in Table- 3 to observe the changing pattern in the growth under different time frame. The long term growth rate may vary with that of a shorter period due to a number of reasons. The CAGR of tea is 7.03 per cent while that of coffee is 11.08 per cent during the period 2001-2017, which shows that demand for coffee has grown at a higher rate than that of tea. The growth in both of these commodities indicates that both the items have a continuous demand, and thus tea futures are feasible as that of coffee. Over the time period of 2007-2017, it is noticed that the CAGR of tea has grown to 10.67 per cent while that of coffee has risen to 12.3 per cent. Thus, both tea and coffee markets seem to have maintained their growth in the international market. During the six years, the exports of coffee and tea have secured a growth rate of
5.87 per cent and 5.77 per cent respectively which clearly reflects that both the commodities have shown more or less similar growth in demand in the short-run period. The trend of CAGR, as shown in Table 3, shows that tea has gained more ground in the export market as compared to coffee in recent times. Good demand and supply condition is well evidenced by the high growth rate in the exports. The greater size of the export market in terms of value reflects its potential for better turnover. Higher turnover means greater scope for earning to the exchequer of the Government. All these fulfil the first criteria for inclusion of futures contracts on tea.

The descriptive statistics on the export value of both tea and coffee has been presented in Table5 , where it is observed that the P-value is greater than 0.05 indicating that the difference between the export value of tea and coffee is not significant. Thus, our first null hypothesis 'There is no significant difference between the price volatility of tea and coffee' is accepted. This connotes that demand for tea is similar to the demand for coffee at the international market. A similar view may be presumed in the domestic market also as there is a close relationship between the domestic market and international market.

Again, the data on the unit price of tea and coffee at the export price (Table 2) have been compared to find out the existence of price volatility in these two commodities. As can be seen in Figure 2, the unit price of tea has been at a higher level throughout the 17 years. Volatile price movements indicate higher market uncertainties and risks requiring risk management which is a primary motivation for fund managers to use the futures market. The level of price fluctuation of tea and coffee for three-time phases namely 2001-2017, 2007 2017 and 2012-2017 has been shown in Table 4, and it is observed that between 2001 and 2017, the price volatility in coffee was higher than that of tea. Nevertheless, gradually, the volatility has narrowed down and matches to the volatility trend of tea. During 2012-2017, both the commodities have shown a reduced variation in 
prices. The coefficient of variation in tea is found to be lower than that of coffee, which is not very low when compared to the price disparity during the period of 2001-17. The presence of price volatility in the tea market calls for the need to manage the risk by providing hedging facilities. This also indicates the feasibility and scope of derivative products in tea.

\begin{tabular}{|c|c|c|c|c|}
\hline \multirow[b]{2}{*}{ Year } & \multicolumn{2}{|c|}{ Exports } & \multicolumn{2}{|c|}{ Export Price } \\
\hline & $\begin{array}{c}\text { Tea }^{1} \\
\text { (INR in Billion) }\end{array}$ & $\begin{array}{c}\text { Coffee }^{2} \\
\text { (INR in Billion) }\end{array}$ & $\begin{array}{c}\text { Tea }^{1} \\
\text { INR/ Kg. }\end{array}$ & $\begin{array}{l}\text { Coffee }^{2} \\
\text { INR/Kg. }\end{array}$ \\
\hline 2001 & 16.82 & 11.37 & 92.13 & 50.81 \\
\hline 2002 & 17.53 & 10.44 & 87.23 & 49.01 \\
\hline 2003 & 15.90 & 11.12 & 91.56 & 50.01 \\
\hline 2004 & 18.41 & 12.04 & 93.14 & 52.73 \\
\hline 2005 & 18.31 & 14.52 & 91.99 & 71.24 \\
\hline 2006 & 20.07 & 19.31 & 91.73 & 78.82 \\
\hline 2007 & 18.10 & 19.07 & 101.26 & 89.03 \\
\hline 2008 & 23.93 & 23.58 & 117.81 & 110.82 \\
\hline 2009 & 27.86 & 19.30 & 140.77 & 107.03 \\
\hline 2010 & 30.58 & 28.78 & 137.75 & 103.21 \\
\hline 2011 & 32.92 & 44.71 & 152.82 & 137.63 \\
\hline 2012 & 37.51 & 46.14 & 180.12 & 152.49 \\
\hline 2013 & 43.55 & 46.25 & 198.81 & 153.40 \\
\hline 2014 & 40.54 & 48.99 & 195.43 & 169.50 \\
\hline 2015 & 43.55 & 50.75 & 190.47 & 170.23 \\
\hline 2016 & 44.68 & 53.62 & 200.86 & 153.88 \\
\hline 2017 & 49.88 & 61.07 & 197.99 & 161.13 \\
\hline
\end{tabular}

\begin{tabular}{|c|c|c|}
\hline \multicolumn{3}{|c|}{ Table 3: Compounded Annual Growth Rate (CAGR) } \\
\hline Year & \multicolumn{3}{c|}{ Exports } \\
\hline $2001-2017$ & 7.03 & Coffee \\
\hline $2007-2017$ & 10.67 & 11.08 \\
\hline $2012-2017$ & 5.87 & 12.34 \\
\hline Source: Calculated from Table 2 & & 5.77 \\
\hline
\end{tabular}

The descriptive statistics on the unit price of both tea and coffee at the export price has been presented in Table 5. It is observed that while the mean values of exports of coffee are higher than that of tea, the mean value of the unit price of tea is higher than that of coffee. The P-value is greater than 0.05 leading to the acceptance of the null hypothesis $\left(\mathrm{H} 2_{0}\right)$ : 'There is no significant difference in the price volatility of tea and coffee' and rejection of the alternate hypothesis. Thus, we conclude that there is no significant difference between the volatility in unit prices of tea and coffee. Again, both the commodities tea and coffee have shown a decline in the price volatility over the period (Table 4). In recent years (2012-2017), although coffee exhibits higher volatility in price when compared to that of the tea, the price disparity in both the commodities has been showing a similar and downward trend. This is indicative of the fact that price changes in tea are similar to the price changes in coffee. 


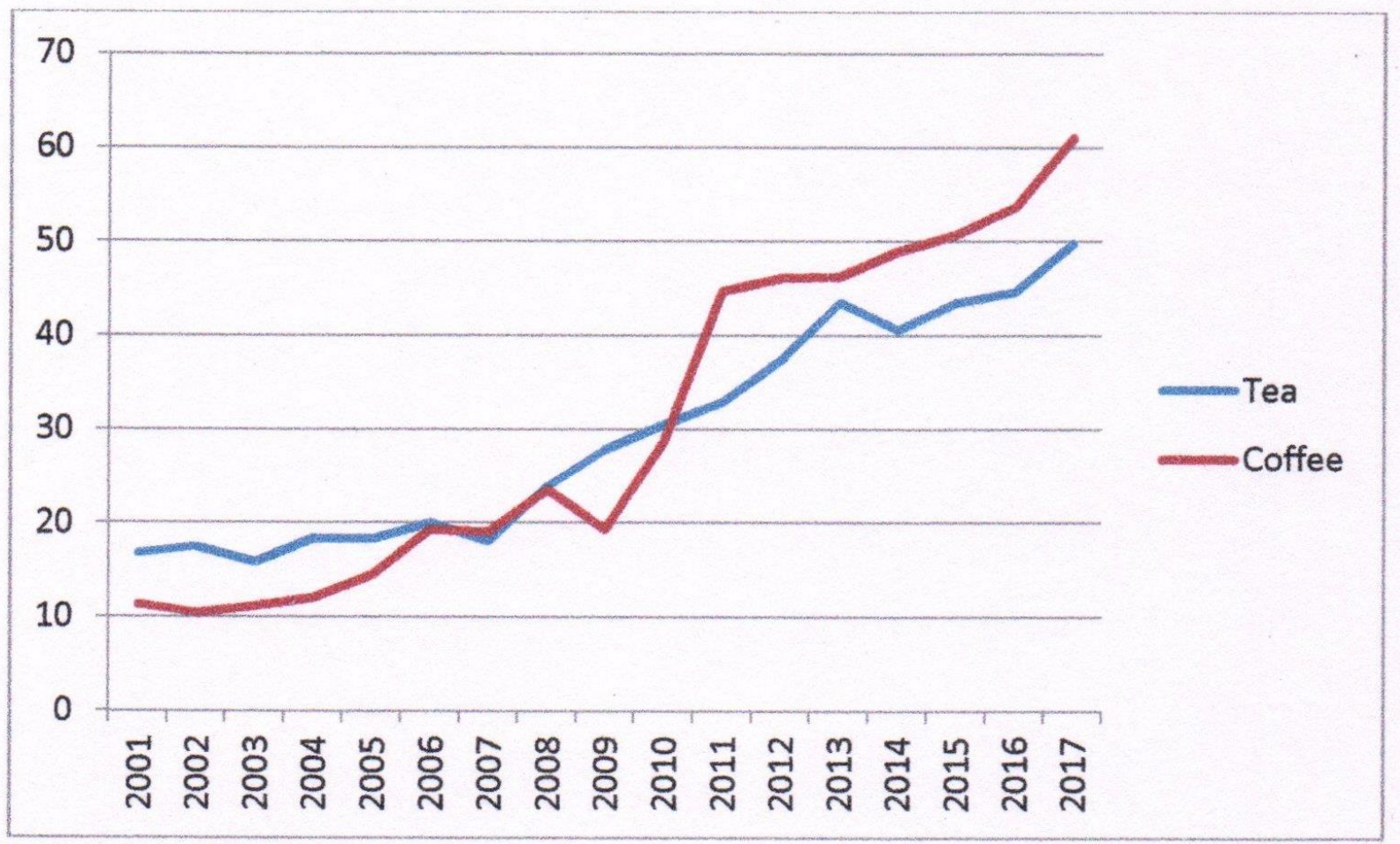

Figure 1: Exports of Tea and Coffee, India Source: Constructed on the Basis of the Data in Table 2

\begin{tabular}{|c|c|c|}
\hline \multicolumn{4}{|c|}{ Table 4: Coefficient of Variation } \\
\hline \multicolumn{3}{|c|}{ Unit Price } \\
\hline Year & Tea & Coffee \\
\hline $2001-2017$ & 33.25 & 41.63 \\
\hline $2007-2017$ & 21.94 & 21.34 \\
\hline $2012-2017$ & 3.95 & 5.10 \\
\hline Source: Calculated from Table 2 & & \\
\hline
\end{tabular}

\begin{tabular}{|c|c|c|c|c|}
\hline \multicolumn{5}{|c|}{ Table 5: Statistical Results } \\
\hline \multirow[t]{2}{*}{ Statistics } & \multicolumn{2}{|c|}{ Export Value } & \multicolumn{2}{|c|}{ Unit Price } \\
\hline & Tea & Coffee & Tea & Coffee \\
\hline Mean & 29.42 & 30.65058824 & 138.9335294 & 109.4688235 \\
\hline Variance & 139.325275 & 317.9647059 & 2134.501774 & 2076.685761 \\
\hline Observations & 17 & 17 & 17 & 17 \\
\hline Pooled Variance & \multicolumn{2}{|c|}{228.6449904} & \multicolumn{2}{|c|}{2105.593768} \\
\hline Hypothesized Mean Difference & \multicolumn{2}{|c|}{0} & \multicolumn{2}{|c|}{0} \\
\hline Df & \multicolumn{2}{|c|}{32} & \multicolumn{2}{|c|}{32} \\
\hline t Stat & \multicolumn{2}{|c|}{-0.237269206} & \multicolumn{2}{|c|}{1.872079467} \\
\hline $\mathrm{P}(\mathrm{T}<=\mathrm{t})$ two-tail & \multicolumn{2}{|c|}{0.813960459} & \multicolumn{2}{|c|}{0.070359442} \\
\hline t Critical two-tail & \multicolumn{2}{|c|}{2.036933334} & \multicolumn{2}{|c|}{2.036933334} \\
\hline
\end{tabular}




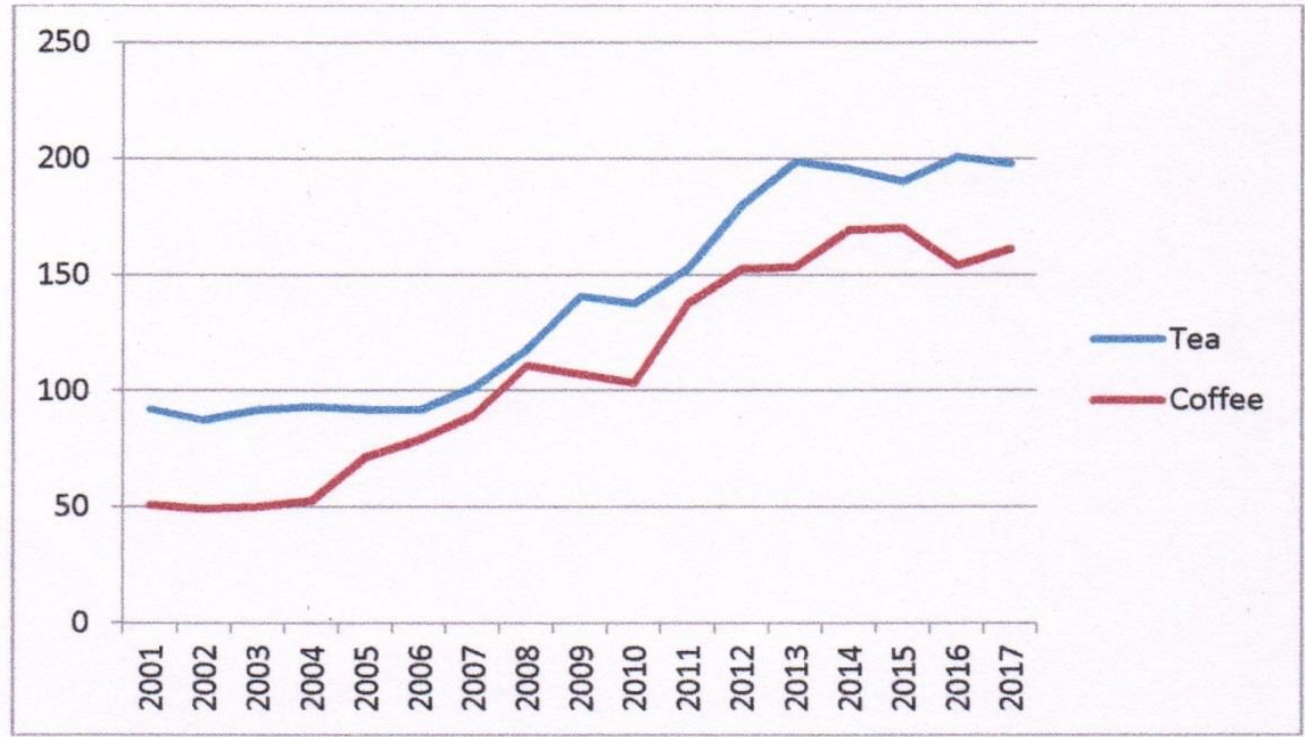

Figure 2: Unit Price of Tea and Coffee, India

Source: Constructed on the Basis of the Data in Table 2

\section{Conclusion}

The Indian futures market covers many commodities in its ambit. The existence of a futures market in tea is absent while it is present in coffee, though both tea and coffee are similar crops in many respects. For this reason, the present study examines the possibility of tea futures vis-à-vis coffee. Our study found that there is a continuous rise in the demand for tea with a similar trend in coffee. Again, it is observed that there exists price volatility in both tea and coffee. Initially, the price volatility in case of coffee is found to be higher than that of tea, but it has narrowed down in recent times, exhibiting a reverse trend. Overall, we found that the demand and price behaviour of tea is more or less similar to those of coffee. These two observations justify the need for the introduction of tea futures in the commodity derivatives market.

In conclusion, it can be said that tea satisfies both the conditions/pre-requisites for the inclusion in the futures market and so far, the prevailing market condition has sufficient ground for launching tea futures in India. This observation is in the context of the fulfilment of the two essential conditions viz. market adequacy and price volatility. However, the other preconditions for the inclusion of tea in the futures market need to be investigated in future research to support the decision with more strength. If tea gets a ground for commodity trading in the futures market, the benefits would be reaped by thousands and millions of tea growers, tea-workers, manufacturers, traders and consumers.

\section{References}

Ahuja, N. L. (2006). Commodity derivatives markets in India: Development, regulation and future prospects. International Research Journal of Finance and Economics, 1(2), 153-162.

Bansal, R., Dadhich, V., \& Ahmad, N. (2014). Indian commodity market - A performance review. International Journal of Management and Commerce, 1(5), 19-34.

Barot, H., \& Gajjar, N.B. (2013). Role and growth of financial derivatives in Indian capital market. International Journal for Research in

Management and Pharmacy, 2(6), 1-23.

Retrieved on 15-08-2017 from

http://www.raijmr.com/ijrmp/wpcontent/uploads/2017/11/IJRMP_2013_vol01_i ssue_06_01.pdf

Bhagwat, S., Maravi, A. S., Omre, R., \& Chand, D. (2015). A study of historical background of Indian commodity market. International Journal of Economic and Business Review, 3(3), 32-43. 
Biswas, S., \& Rajib, P. (2012). Testing price volume relationships for Indian commodity futures. Journal of Indian Business Research, $3(2), 117-131$.

Brorsen, B. W., \& Fofana, N. F. (2001). Success and failure of agricultural futures contracts. Journal of Agribusiness, 19(2), 129-145.

Retrieved on 10-06-2017 from http://citeseerx.ist.psu.edu/viewdoc/download ?doi=10.1.1.515.6248\&rep=rep1\&type=pdf

Bryant, H. L., \& Haigh, M. S. (2004). Bid-Ask spread in commodity futures markets. Applied Financial Economics, 14(13), 923-936, https://doi.org/10.1080/096031004200028466 9

Department of Agriculture, Cooperation and Farmers Welfare. (2019). Annual Report 201819. Ministry of Agriculture and Farmers Welfare. Government of India. Retrieved on 1001-2020 from

http://agricoop.nic.in/sites/default/files/AR_20 18-19_Final_for_Print.pdf

Dey, K., \& Sivakumar, A. (2012). Do futures benefit Indian coffee producers?. International Journal of Economic Policy in Emerging Economies, 5(4), 318-

341.doi: 10.1504/IJEPEE.2012.052303

Hosseini-Yekani, S. A., Zibaei, M., \& Allen, D. E. (2009). The choice of feasible commodities for futures trading: A study of Iranian agricultural commodities. African Journal of Agricultural Research, 4(3), 193-199. Article D16E00D33722. Retrieved on 09-09-2017 from https://academicjournals.org/journal/AJAR/arti cle-abstract/D16E00D33722

Kaur, G., \& Rao, D. N. (2009). Do the spot prices influence the pricing of future contracts? An empirical study of price volatility of future contracts of selected agricultural commodities traded on NCDEX.

https://dx.doi.org/10.2139/ssrn.1469700

Kumar, B., Banga, G., \& Jindal, A. (2012). Perception and attitude of farmers and agricultural firms towards commodity finance. NMIMS Management Review, 22, 89111.Retrieved on 20-07-2018 from https://pdfs.semanticscholar.org/ffc $7 / 32574 d c$ bd2f46cdcbdd8602426b69319598c.pdf

Kumar, B., \& Pandey, A. (2009). Role of Indian commodity derivative market in hedging price risk: Estimation of constant and dynamic hedge ratio and hedging effectiveness. Indonesian Capital Market Review, 3(1), 59-79. doi: $10.2139 /$ ssrn.1452881

Lokare, S. M. (2007). Commodity derivatives and price risk management: An empirical anecdote from India. Reserve Bank of India Occasional Papers, 28(2), 27-77. Retrieved on 28-02-2018 from

https://www.rbi.org.in/scripts/PublicationsVie w.aspx?id=10204

Mallikarjunappa, T. (2012). An analysis of the risk-return relationships of Indian commodity futures market. Anveshana, 2(1), 3-41.

Retrieved on 13-04-2017 from

http://www.ijrar.org/papers/IJRAR19QP018.pdf

Maravi, A. S. (2015). Performance analysis of Indian agricultural commodity market. IRACST International Journal of Commerce, Business and Management, 4(2), 1125-1135.

Mukherjee, K. (2011). Impact of futures trading on Indian agricultural commodity market. Munich Personal RePEc Archive. Article 29290. Retrieved on 16-07-2017 from http://mpra.ub.uni.muenchen.de/29290 Naik, G., \& Jain, S. (2002). Indian agricultural commodity futures market: A performance survey. Economic and Political Weekly, 37(30), 3167-3173.

Nath, G. C., \& Lingareddy, T. (2008). Impact of futures trading on commodity prices. Economic and Political Weekly, 43(3), 18-23.

Pennings, J., \& Leuthold, R. M. (2001). A behavioural approach towards futures contract usage. Australian Economic Papers, 40(4).https://doi/10/1111/1467-8454.00137

Qehaja, L. (2014). Feasibility studies on future exchange of agricultural commodities in Kosovo [Thesis, Rochester Institute of Technology]. Retrieved on 05-05-2019 from http://scholarworks.rit.edu/theses/8113/ 
Raipuria, K. (2001). Report of the Group on Forward and Futures Markets. Department of Agriculture and Cooperation. Government of India. Retrieved on 17-03-2016 from http://www.fmc.gov.in/WriteReadData/links/re port7-925109181.pdf

Rajib, P. (2014). Commodity derivatives and risk management. PHI Learning Private Limited.

Ravi, S. (2013). Price discovery and volatility spillover in Indian commodity futures market using selected commodities. PARIPEX-Indian Journal of Research, 2(12), 128-130. https://www.doi.org/10.36106/paripex

Roy, A. (2006). Indian agricultural commodity market, risk management and its sustainable growth: An integrated framework, https://dx.doi.org/10.2139/ssrn.1178702

Sharma, K. (2013). A study of commodity futures in India: Perception towards commodity futures trading in India with special reference to commodity futures exchange. International Journal of Asia Pacific Journal of Research, 2(4), 1-6.

Shim, E. (2006). Success factors of agricultural futures markets in developing countries and their implication on existing and new local exchanges in developing countries [Dissertation, Tufts University]. Retrieved on 12-03-2018 from https://dl.tufts.edu/concern/pdfs/vt150v994

Singh, J. B. (2004). Futures market in management of price risks in Indian agriculture. Finance India, 18(2), 947-952.
Sivarethinamohan, \& Aranganathan, P. (2013). A study on investors' preference in Indian commodity markets. European Journal of Commerce and Management Research, 2(1), 915. Retrieved on 10-02-2018 from https://www.ejcmr.org/files/January\%202013/ ARTICLE_3_JAN_2013.pdf

Zhang, J. (2012). The feasibility and challenges of introducing futures exchange to the shrimp markets [Master Thesis, Norwegian School of Economics Bergen]. Retrieved on 03-04-2017 from https://openaccess.nhh.no/nhhxmlui/bitstream/handle/11250/169995/Zhang_ 2012.PDF?

\section{About the Authors}

Rajat Bhattacharjee has been working as Assistant Professor in Royal School of Commerce under Royal Global University since 2013. He is presently pursuing his Ph.D. course in Commerce under Gauhati University. His research interest lies in areas of finance, accounting and taxation.

Santosh Kumar Mahapatra, completed his M.Com. and M.Phil. from Berhampur University and Ph.D. from Gauhati University. He has 31 years of teaching and research experience. His area of interest is banking and finance.

\section{Acknowledgements}

We would like to extend our heartfelt gratitude to the reviewers for their time and efforts which contributed to the development of the paper. 